\title{
Poverty in Poland and the United States: A Comparison of Key Characteristics, Composition, and Prospects
}

\author{
Bozena Leven \\ Economics Department, School of Business, The College of New Jersey, Ewing, USA \\ Email: bleven@tcnj.edu
}

Received 20 February 2016; accepted 2 May 2016; published 5 May 2016

Copyright (C) 2016 by author and Scientific Research Publishing Inc.

This work is licensed under the Creative Commons Attribution International License (CC BY). http://creativecommons.org/licenses/by/4.0/

c) (i) Open Access

\begin{abstract}
This study provides a comparative approach to assess the state of Polish poverty. To do so, poverty in Poland and the United States is presented in terms of selected general, shared characteristics and particularly vulnerable societal groups. Using official, primarily income based, statistics for Poland and the United States, we conclude that a higher percentage of the overall population in the United States is poor and, relative to median country-specific incomes, that the US poverty is deeper than in Poland. In addition, more children, the elderly, and the disabled are poor in America than in Poland; the breadth of poverty is wider in the United States and, perhaps most importantly, may in some important ways also be more intractable.
\end{abstract}

\section{Keywords}

Measurement and Analysis of Poverty, Comparative Studies of Poverty

\section{Introduction}

While poverty exists in all the countries, its extent, depth and characteristics differ greatly. Comparative studies of poverty are difficult because poverty in Africa, Europe or the United States poses very different realities for those living there. Comparing poverty is also challenging as individual countries rely on differing statistical methodologies and data on poverty are notoriously problematic. While the characteristics and causes of poverty are diverse and often country specific, however, there are some basic commonalities generally shared by the poor across countries, as they tend to belong to similar societal groups.

In this study we broadly describe the characteristics of poverty in Poland and compare it to poverty in the United States. Analyzing Polish poverty is a relatively new endeavor, because prior to its transition in 1990 to a 
market economy, Poland under socialism was "poverty free” according to official state sources. Pre-transition, the State provided cradle to grave assistance, taking care of all basic needs, including health care, education, and subsidized housing and day care. Full employment was a key economic objective of the State and all prices (including food and energy) were set for prolonged periods of time. Consequently, there was no open unemployment or inflation and no need for welfare or social benefits. And, since all wages were controlled by the State, Poland experienced relatively equal income distribution, though relevant data for that period are not always reliable.

As the transition to a market economy progressed, liberalization and privatization reforms led to unemployment, inflation, income polarization and rising poverty. Rising income inequalities were exacerbated as Poland's economy grew and private ownership expanded, leading to wealth accumulation and newly established foreign, as well as private, firms, which often paid premium wages for selected skills. Rapid growth and development in the late 1990s and early 2000, combined with an accelerated integration of technology, created opportunities for selected workers, while leaving multiple societal groups with a sense of real and/or relative deprivation.

Significantly, rising inequality and poverty in Poland were a cornerstone of the recent 2015 presidential elections, and will likely serve as a metric against which the current government will be assessed in the short and medium-term by Poland's electorate. Poles, who feel marginalized, either in absolute or relative terms voted for politicians who spoke to this sense of marginalization. Today's Poland is sharply divided between those who benefited from transition and those who were left behind, as is clearly reflected in a deep, persistent policy divergence between the country's two main political parties. Considering Poland's poverty relative to one of the wealthiest countries in the world may broaden and enrich the perspectives of those now focused on this issue.

The choice of the US for developing a different perspective on Poland's poverty is dictated by several reasons. To begin with, most Poles believe that the United States is the world's richest country and enjoys the highest standard of living (despite often contrary statistical data) and know little about its economic problems. These misperceptions are based, in part, on historical reasons. For years, Poles were exposed to a steady stream of propaganda critical of America from a widely distrusted State media propped up by Poland's eastern neighbor. At the same time, American entertainment outlets presented a picture of the United States as a nation of abundance. The resulting positive image of the United States was reinforced by the power of the dollar on the domestic black currency market in the pre-transition period. Savings maintained in dollars at that time permitted those Poles who had accumulated even small amounts to substantially increase their standard of living.

Today, this same wealth perception is continuously reinforced by the media, as American made entertainment still dominates Polish television and cinema. And this image is unlikely to change in the near future, as expansive, stringent American visa requirements-in marked contrast with the open borders within the EU—actively hinder many Poles from experiencing a different reality by visiting or working in the United States.

Comparing Poland to the US in any economic aspect is inherently problematic. Recognizing the major differences in size, population and levels of development in the US and Poland, we rely exclusively on relative poverty measures for each country in our analysis. A better understanding of how poverty in the United States and Poland differ, and where they are similar, may help inform how Polish society evaluates its own problems and its current anti-poverty policies. Since some of data used are based on census or surveys for comparability purposes most of the recent data used cover years 2010-2013.

\section{The Literature on Poverty-Review}

There are numerous definitions of poverty, focusing on absolute and relative measures. Absolute poverty measures poverty in relation to the amount of money necessary to meet basic needs such as food, clothing, and shelter and is not concerned with broader quality of life or income inequality [1]. Relative poverty defines poverty in relation to the economic wellbeing of other members of the society: people are poor if they fall below selected standards in a country [2]. Both concepts, however, are largely concerned with income and consumption.

In addition to problems in defining poverty, literature on poverty often includes an analysis of the methodological differences and related problems embedded in the relevant statistical data. Several major international organizations that collect primary poverty data have devoted substantial resources to developing unique methods for assessing poverty. The most extensive poverty studies originate from various UN departments, the World Bank, the OECD, and other international organizations that research and combat poverty. For example, The Annual Human Development Report, funded as part of the United Nations Development Program, is a major 
source of international poverty data and analysis that has frequently revised its poverty measures to address numerous methodological problems.

While measuring poverty in any single country is challenging, cross country comparisons are even more problematic since they require some degree of compatibility of the indicators used. When selecting poverty indicators for cross country comparisons, the literature focuses on a proper selection of poverty thresholds for individual country, which then determine and define the extent and depth of poverty. Use of such thresholds alone is problematic as described by Atkinson [3], due to differences in the purchasing power of incomes across countries, and the common failure to adequately account for non-cash, state provided subsidies/benefits, such as health care, education and housing, or other benefits available in different countries. Thus, cross country poverty analysis often involves individual country measures beyond income-based indicators. Unfortunately, since these benefits differ by country, Smeeding [4], they add to the complexitiy of those cross-country studies. Overall, while there is a consensus in the literature that income-based indicators need to be supplemented by other complex measures, there is no consensus on a better multi-dimensional approach, as discussed by Sen [5].

Given those poverty data problems, in addition to average income-based statistics, cross-country comparisons rely also on medians and other percentiles describing income distribution, particularly when averages are less representative due to severe income inequalities. Furthermore, aside from income, another frequently employed approach involves spending indicators Sahn [6], which shed more light on households' ability to finance their basic needs but require use of numerous assumptions about spending patterns and non-cash benefits. Another poverty measure beyond those linked to income incorporates additional data on life expectancy, health, nutrition, and education through the Human Development Index (HDI), which is reported annually for all countries in the Annual Human Development Reports. Because As the HDI index requires preselecting weights for each indicator, however, it is sometimes also considered to be also arbitrary [7].

Given these methodological challenges, a multi-dimensional approach best captures situations in which a country specific monetary and non-monetary benefits are used to assess the depth and extent of poverty [8]. In addtion, a number of poverty studies identify societal groups most frequently affected by poverty within specific countries, and then compare them to the same societal groups across countries [9]. The societal groups examined typcially include children, women, and the elderly. For example, the World Bank and the Luxembourg Center for Population, Poverty and Public Policy and UNICEF [5] have conducted various studies of societal groups most affected by poverty, including complex research on the demographics of poverty, child poverty and its gender component [10].

In this study we rely on several income based measures of poverty for both countries, as well as a comparison of the extent of poverty in similar societal groups. To the best of our knowledge, no study generally compares poverty in Poland and the United States using the measures described below, or compares our selected societal groups.

\section{Differences in Measuring Poverty Rates: Poland vs. US}

There is substantially more data and studies on poverty in the United States than in Poland. However, as transition progresses and income inequality has increased, the topic of poverty has become more important in Polish language literature, published primarily by the government funded Main Statistical Office (GUS), private foundations [11] and some academic institutions.

As with all such studies, both Polish and US poverty data pose a series of methodological problems. In particular, the United States Bureau of Census measures poverty by comparing income to as elected poverty threshold for households of a given size, using it uniformly across the United States, despite major regional cost of living differences. In 2012, the average poverty threshold for a household of four was $\$ 23,492$ annually. This income-based measure ignores household housing conditions, debt levels, financial assets (including savings or property), capital gains, or non-cash benefits (such as public housing, Medicaid, or food stamps).

In Poland, the major income-based poverty measure is calculated as 60 percent of the median income, also adjusted for household size. In 2012, that threshold for a household of four was 1863 PLN per month, or about $\$ 7460$ yearly [11]. As in the US, this measure also ignores real and financial household assets (though these are significantly lower than in the United States), access to subsidized housing (more common in Poland than the US) and is also not geographically adjusted (although Poland is significantly smaller in size, and less regionally diversified, then the United States). 
However, the three-to-one income ratio of those rough poverty measures in the United States and Poland closely matches the ratio of their respective GDP per capita, which is $\$ 44,439$ versus $\$ 14,710$ [12]. Using the above income-based approach in 2012 poverty rates in the United States and Poland were 15 and 6.8 percent, respectively.

In addition to these income-based poverty statistics, both Poland and the United States also employ additional ways of measuring poverty by incorporating housing quality, the ownership of various consumer goods, and the ability to provide adequate heating. But, as previously noted, these country-specific measures are not used in a systemic way and therefore are problematic when comparatively assessing economic quality of life.

Aside from measuring absolute poverty, international comparisons rely on various relative poverty measures, in which the "depth" of poverty is considered. One such measure involves the percentage of population/households receiving less than 60 percent of the average income [13]. In 2011, those numbers were 17.1 percent and 11.1 percent, respectively, for the United States and Poland [14]. Another relative poverty indicator accounts for the percentage of people with income 50 percent below the poverty line, which are often referred as those living in deep poverty. In the United States, 6.6 percent of population lived in deep poverty in 2012 and in Poland that number was 6.1 percent (using a rough equivalent poverty measure of the percentage of the population living below the "existential minimum") [15]. This "existential minimum" denotes the lowest income that enables the purchase of a selected modest basket of identified consumer goods and services.

In addition to absolute and relative poverty rates, poverty gap measures are also sometimes considered, when calculated as the difference between the poverty line and the median income of those below the poverty line. The poverty gap in 2012 was 20.6 percent for Poland and 27.5 percent for the United States [16].

For the reasons previously noted, these statistical poverty income linked measures do not imply that the poor in one country are comparatively better off than their counterparts in another. This is particularly true where, as here, there is a high degree of income inequality between the United States-GINI coefficient in 2011 was 45.0, and Poland with a 32.7 percent GINI coefficient [17].

Nevertheless, these data do show that, by country-specific measures, the incidence of poverty in the United States is higher than it is in Poland by every indicator presented. Moreover, as appears below, this overall conclusion also applies to societal groups that are typically overrepresented among the poor.

\section{Who Are the Poor: Poland vs, the US}

\subsection{Age}

According to the literature, the largest poverty clusters are typically found among those who are the most economically vulnerable: children and the elderly. As indicated by Table 1 , the incidence of poverty for children in the United States is higher than for children in Poland, regardless of the income threshold used. Furthermore, as per Table 2, in 2011, 16.6 percent of American children lived in poverty set at a threshold of 40 percent of average income and these numbers increase to 21.1 percent when the poverty threshold is set at 50 percent of average income and to 31.1 percent when 60 percent of average income is used.

When using the US national poverty threshold for 2012, American children living in poverty represented fully 23.7 percent of the total U.S. population, constituted 34.6 percent of all Americans in poverty, and accounted for 35 percent of Americans living in deep poverty. Using a roughly equivalent Polish measure (i.e., 40 percent of

\begin{tabular}{ccc}
\hline Table 1. US and Poland's key poverty measures. & \\
\hline Measure/in percentage in 2012 & US & Poland \\
\hline Income determined poverty & 15 & 6.8 \\
Relative poverty & 17.1 & 6.1 \\
Deep poverty & 6.6 & 27.5 \\
Poverty gap & 20.6 & 14.1 \\
Of all poor, those under 18 & $22^{*}$ & 10.9 \\
\hline
\end{tabular}

2010 Sources: Ubostwo w Polsce w swietle badan GUS, Studia i Analizy, GUS, Warszawa, 2013. 
average income), 7.5 percent of Poland's children are poor (as opposed to 16.6 percent in the United States). This difference between countries diminishes as the poverty line threshold increases from 40 to 50 and 60 percent of average income, indicating that poverty is shallower among Polish children.

When the characteristics of children living in poverty are examined there appears to be a key difference between the two countries, in the US the race of the child appears to be a key factor, while in Poland the size of a household matters. As indicated in Table 3, almost three quarters of all children living in poverty in the US almost three quarters are Black or Hispanic.

While Poland's homogenous society does not have an analogous racial component, household size (number of children) does play a role in poverty status. In 2010, 34 percent of Polish families with 4 or more children fell below the poverty threshold [13]. By contrast, the number of children in a household does not appear to be related to poverty in the United States.

\subsection{The Elderly}

Measuring poverty among the elderly through income-based statistics is particularly problematic, because in both countries members of this group often rely on various transfer payments and non-cash benefits unavailable to other groups that are not captured in official income data. Moreover, these benefits differ substantially in Poland and the United States. While seniors in both countries have access to health care, in Poland that access is free of charge (although quality and wait times can be problematic) while American seniors often pay high outof-pocket costs but are far less constrained by long wait times for care. In addition, many seniors in the United States supplement their social security income by working past their retirement age, which is rather unheard of in Poland. Poland's current retirement age is also lower than the US and often profession specific, inflating the number of Poles eligible for senior benefits. Furthermore, official poverty data in both countries often ignore savings and accumulated non-financial assets that directly impact the well-being of seniors, which further complicates comparative poverty studies of that group.

These concerns about measuring poverty among US seniors prompted the US Census Bureau to develop an alternative measure, which deducts health care expenses from income. This is known as the supplemental poverty measure and, under it, poverty in the United States among the elderly increased from 9 percent in 2007 to 15 percent using unadjusted data in 2011 [18].

Poland provides universal health care and no attempts have been made to adjust income of the elderly for health care expenses. The reliance of some seniors on private health care and rising co-payments for prescription drugs would tend to bias Poland's poverty measures downwards, as compared to the United States. In Poland,

Table 2. Child poverty rates Poland vs. US-2011.

\begin{tabular}{cccc}
\hline $\begin{array}{c}\text { Percentage of } \\
\text { children }\end{array}$ & $\begin{array}{c}\text { Poverty line at } 40 \text { percent } \\
\text { of average income }\end{array}$ & $\begin{array}{c}\text { Poverty line at } 50 \text { percent } \\
\text { of average income }\end{array}$ & $\begin{array}{c}\text { Poverty line at } 60 \text { percent } \\
\text { of average income }\end{array}$ \\
\hline US & 16.6 & 21.1 & 31.1 \\
Poland & 7.5 & 14.5 & 22.9 \\
\hline
\end{tabular}

Source: http://www.unicef-irc.org/publications/pdf/rc10_eng.pdf

Table 3. US children living in poverty, 2010.

\begin{tabular}{cc}
\hline Category & Percent \\
\hline All children under 18 & 22.0 \\
White only, non-Hispanic & 12.4 \\
Black & 38.2 \\
Hispanic & 35.0 \\
Asian & 13.6 \\
\hline
\end{tabular}

Source: U.S. Bureau of the Census, Income, Poverty, and Health Insurance Coverage. 
approximately 4 percent of all people over 65 were classified as poor in 2012, using a poverty threshold of 60 percent of median income adjusted for household size. As a percentage of all poor, Poland's seniors held a 14.7 percent share in 2011, which doubled from a 7.3 poverty share in 2005. However, this increase is partially methodological and, given Poland's increasing income polarization and income growth, use of median income as a poverty threshold indicates an increase in relative, not absolute, poverty [4].

There are some housing market differences between Poland and the US that can also affect the accuracy of poverty measurements in this age group. In Poland, many seniors pay relatively lower housing costs than other societal groups, which is a legacy of the socialist period. The relatively limited mortgage market and regulatory restrictions on Polish rentals left most seniors in apartments inherited from the pre-transition period, which are either leased or purchased from the State at below market rates as a part of the privatization process. Thus, although housing costs are not captured by poverty statistics in either country, they tend to more negatively affect the elderly in the United States, such that Poland's data on poverty among seniors likely suffers from some degree of upward bias. While poverty data among the elderly in both countries contain some serious limitations, regardless of the measures used the elderly in Poland and the United States constitute a substantial share of all poor in both countries and their actual poverty rates are likely to exceed those reported using income threshold poverty measures.

\subsection{Poverty and Education}

In addition to age, there is broad consensus in the literature that education, a key factor influencing income, also determines the incidence of poverty. While lack of education contributes to poverty, an individual's access to quality education is related to income status. Consequently, education is both a cause and effect of poverty. In the United States and Poland primary and secondary education is funded mostly by local communities; therefore, the quality of teachers, teaching materials, and course specialization (e.g., specific offerings in computer science, foreign languages, music, etc.) are linked to the affluence of a particular community. Generally, aside from government subsidies, low income communities in both countries are less able to fund education at the same level as high income communities.

Measuring and comparing the quality of primary and secondary education in different countries is an inherently difficult task. One generally applied measure involves the PISA score used internationally to rank the quality of education. Using PISA rankings, Poland scored $9^{\text {th }}$ in 2012, with a mean score of 518, while the United States ranked $31^{\text {st }}$ with a mean score of 481 [12].

The quality of primary and secondary education, in turn, impacts access to tertiary education, which is itself a key factor inversely linked to poverty. In that respect, American universities are ranked among the best in the world, whereas Poland lags far behind in this category. Aside from quality, there are, however, some characteristics of tertiary education that favor Poland, particularly in terms of enrollments and costs. In 2012, almost half of Poland' full time students attended public, tuition free universities. For those attending private schools, tuition ranged between $\$ 800$ - $\$ 3000$, representing less than 25 percent of Poland's average annual income (approximately $\$ 13,000$, with the median being $\$ 12,700$ ), only 10 percent of Polish students financed their education through loans and, surprisingly, 80 percent of those receiving loans attended public schools.

Overall, higher education in Poland is far more accessible for less affluent groups than it is in the US. Moreover, for Poland's less privileged access to higher education is increasing. During the 1994-2010 period, the difference in high education enrollments between the $1^{\text {st }}$ and the $5^{\text {th }}$ income quintile increased from 13.3 percentage points in 1994 to 40.5 percentage points in 2005, falling to 30.5 percentage points in 2008 [19]. Aside from the changing labor market in Poland, which makes higher education more important over time, transition led to the formation of private colleges and universities in medium and small size cities. Given Poland's relatively severe legal restrictions on the rental market (and consequent high rents), shortening physical distances between students and universities increased access to higher education in smaller towns, which are often located in most impoverished areas.

The high quality of higher education in the United States comes with high costs, as tuition averaged $\$ 15,000$ for public, and over $\$ 35,000$ for private, schools in 2014. These costs substantially exceed international averages, and constitute a high entry barrier for many students. As a result, many more American than Polish students finance their education through loans and accumulate substantial debt. For example, in 2012, the average student loan balance in the United States was $\$ 24,301$, with one-quarter of borrowers owing more than $\$ 28,000$ and 10 
percent of borrowers owing more than $\$ 54,000$ upon graduation [20].

Over the last 25 years the relative increase in Polish tertiary education enrollments outpaced US equivalents in relative terms; as the demand for new skills escalated, the supply of Polish universities increased. Specifically, between 1995 and 2010, tertiary enrollment rates within the 20 - 29 years old age group increased from 15 percent to 30 percent, with a greater number of women entering colleges and universities. During that same time period college participation rates in the United States also increased, but at a slower pace, rising from 19 to 25 percent [21]. These limited data suggest that Poland's higher educational system, though lagging the United States in quality, is less costly and, therefore, more accessible to a relatively higher number of students. Since education may well be the single most important factor affecting poverty levels, Poland's relative advantage here has likely played, and will continue to play, an important role in explaining the above-cited differences in poverty between the two countries.

\subsection{Poverty and Disability}

Disability is another characteristic linked to poverty. In 201018.7 percent of the U.S. population had some form of disability and 12.6 percent were considered severely disabled. For those disabled persons aged 18 to 64 , the poverty rate was 28.4 percent (4.3 million); that is, more than twice the poverty rate of 12.5 percent (22 million) for Americans in that age category who were not disabled in 2012.

The poverty rate for disabled Polish adults was 9.6 percent in 2010 [13], and declined to just 3 percent by 2012. That decline is largely attributable to changes in Poland's disability legislation, which substantially tightened the definition of disability and eligibility criteria for obtaining that status [22]. The relatively low poverty rate among Poland's disabled also results, in part, from statistical methodology. In Poland, disability benefits are typically replaced with state pensions upon a disabled person attaining retirement age, which removes that person in poverty from the "disabled" to the "pensioner" category. By contrast, disabled Americans maintain their disabled status regardless of age and are often not eligible for full Social Security benefits, but instead receive a much lower SSA supplemental payment.

As in the other categories, comparing poverty among people with disabilities in both countries poses challenges. Aside from data problems that impede accurate calculations, it is difficult to establish equivalent, direct and indirect benefit values received by each disabled population. Despite those constraints, two basic conclusions can be drawn: disability is an important factor affecting poverty in both countries; and there are relatively fewer disabled Poles than disabled Americans living in poverty.

\subsection{Geography of Poverty}

Across the world poverty tends to cluster geographically. In the last 25 years, Poland's growth and development most positively affected large cities and its western regions. Some of the reasons for this geographical disparity of development are rooted in historical differences in regional development, urbanization, the quality of infrastructure, concentration of foreign direct investment, and availability of skilled labor. In Poland, which is divided into 16 districts (vojevodships), the highest incidence of poverty, regardless of the poverty measures used, is concentrated in two regions considered to be Poland's least developed: Swietokrzyskie, (11.9 percent) and Warminsko-Mazurskie (11.7 percent). The lowest poverty rates are in Opolskie (4.7 percent) and Lubuskie (4.8 percent), which are located in the most developed part of the country [23].

The two areas with the highest poverty rate exhibit high structural unemployment rooted in the elimination of large state farms and manufacturing companies (along with their related supply chains) through privatization, and the predominance of small towns in those regions (i.e., with populations under 50,000). This is particularly apparent in Warmiensko-Mazurskie, a region that relied heavily on state-guaranteed jobs, along with free or heavily subsidized housing and multi-layered social services for all employees. Many of those state jobs in agriculture and manufacturing required limited education, and therefore became obsolete as Poland transitioned to a new market economy, causing structural unemployment to skyrocket in these regions.

Another high poverty region in Poland — the Kieleckie region—shares the same problems rooted in privatization, structural unemployment of unskilled labor and poor infrastructure. The structural unemployment here is also linked to heavy industry firms (outside of coal and steel) that could not compete when Poland's opened its borders to western markets. Closingstate farms in a world with slowly improving infrastructure limited private sector formation and the inflow of domestic and foreign investment leading, in turn, to long-term structural un- 
employment and poverty.

By contrast, Poland's regions with the lowest incidence of poverty (Slaskie, Lubuskie, and Opolskie) are among the most developed, the most urbanized, and enjoy the best infrastructure. These regions also benefit from their proximity to Germany, which has facilitated significant (albeit often temporary) migrations and consequent transfers of remittances, as well as FDI inflows, to those regions. In combination, these remittances, FDI and developed infrastructure further increased urbanization, fueled growth, spurred employment, and contributed to a decline in regional poverty.

Poverty in the United States is also clustered geographically. In 2010, the average US poverty rate was 15.9 percent, and the states with the highest poverty rates included Mississippi (22.6), New Mexico (21.5), and Louisiana (20.4). The lowest rates were in New Hampshire (8.8), Maryland (10.1), and New Jersey (10.4), respectively [24].

Factors affecting the regionalization of Poland's poverty; i.e., poor infrastructure and a low degree of urbanization - do not appear to play a discernible role in the geographic distribution of poverty in the United States. In fact, urbanization levels in the states with the lowest poverty rates, such as New Hampshire (60.3 percent), are lower than in the two states with the highest poverty rates-New Mexico (77.4 percent) and Louisiana (73.2 percent). Additionally, poverty clusters exist in such highly urbanized locations as the Houston, Texas metropolitan area, with a record 37.7 percent incidence of poverty in 2011, the Fresno, California metro area-25.8 percent, and the El Paso, Texas metro area—24.7 percent [24] Detroit, Michigan—44 percent in poverty (of whom 18.5 percent were in deep poverty), and East St Louis, Illinois-50.8 percent in poverty (of whom 19.5 percent were in deep poverty) [25].

The reasons for regional clusters of poverty in both countries differ. In Poland, the geographical distribution of poverty is mainly a legacy of its central planning heritage; that is, concentrated privatization of state farms and heavy industry, and the related slow development of modern infrastructure and the private sector in those areas. In the United States, geographical poverty clusters seem unrelated to infrastructure. Instead, they are concentrated in areas with high minority populations, which is a factor completely absent in Poland. For example, states like California, where Hispanics constitute 60.6 percent of the total population, and portions of Texas (Maverick County, Webb County, and Starr County, being 96.8, 96.4, and 96.1 percent Hispanic, respectively) are each burdened with large poverty clusters [6].

However, regional poverty in Poland and the United States do share a common characteristic-structural unemployment. And in both countries, that shared feature reflects changes in markets: in Poland structural unemployment is caused by privatization of state farm and factories and a declining demand for unskilled and semi skilled labor. In the US, the causes of structural unemployment generally reflect a decline in manufacturing caused by cheaper imports and the changing composition of labor market demand.

\section{Unique Characteristics of the Poor: Poland vs. US}

As indicated above, one key factor associated with poverty in the United States is race. In 2012, 27 percent of African Americans and 25 percent of Hispanics lived below the official poverty threshold [7]; Hispanics are more than twice as likely, and African Americans almost three times more likely, to live in deep poverty than non-Hispanic whites. Specifically, in 2012, 12.7 percent of blacks (almost 5.1 million), 10.1 percent of Hispanics (almost 5.4 million), and 4.3 percent of non-Hispanic whites (8.4 million) were living in deep poverty.

Another characteristic of the poor in the United States is their marital status. In 2012, almost 31 percent of households headed by a single woman were living below the poverty line-being nearly five times the 6.3 percent poverty rate for families headed by married couples [7]. Sixteen percent of households headed by a single male were living in poverty.

As Poland's society is homogeneous, race is not a factor among the poor. At the same time, family structure plainly matters, and Poland's family structure is relatively intact, with only 12 percent of families being headed by single mothers [10]. More importantly, of those families only 6 percent are in poverty [13]. What distinguishes Polish poverty in terms of family structure is its size—as mentioned above those families with 4 or more children have a significantly higher incidence of poverty.

Consequently some of the key roots of poverty in the US and Poland are very different: while race and marital status are important predictors of US poverty, in Poland, those are not are irrelevant factors. Instead, family size and place of residence tend to explain some of the poverty causes. 


\section{Conclusions}

Based on official poverty data in the United States and Poland, there are substantial differences, by societal groups, in the composition of the poor. Overall, a higher percentage of the overall US population is poor than in Poland and, relative to median country—specific incomes, US poverty is deeper. Among the groups that tend to be more vulnerable to poverty, relatively more American children and a higher percentage of persons aged 65 and older are poor than in Poland. In addition, more Americans than Poles are considered disabled, and in this group, a higher percentage of disabled Americans live in poverty.

As often discussed in the literature poverty indicators have severe limitation, as they often fail to provide a basis for comparing the standards of living of the societal groups across countries, do not accurately capture the purchasing power of income, and ignore numerous non-cash benefits that affect how well, or poorly, people actually live.

These poverty measures do, however, provide us with the general understanding that on relative terms poverty is wider in the United States than in Poland and, perhaps more importantly, suggest that poverty in America may also, in some important ways, be more difficult to address through government policies. In the United States the link between minority status, single parent households, and poverty is widely recognized. In Poland, large families are most likely to experience poverty. If family size in Poland is easier to address than the incidence of single parent households in minority communities, poverty in the US may also prove be more intractable.

\section{References}

[1] Hagenaars, A. and De Vos, K. (1988) The Definition and Measurement of Poverty. Journal of Human Resources, 23, 211-221. http://dx.doi.org/10.2307/145776

[2] Vos, K.D. and Garner, T.I. (1991) An Evaluation of Subjective Poverty Definitions: Comparing Results from the US and the Netherlands. Review of Income and Wealth, 37, 267-285.

http://dx.doi.org/10.1111/j.1475-4991.1991.tb00371.x

[3] Atkinson, A. (1987) On the Measurement of Poverty. Econometrica, 55, 749-764. http://dx.doi.org/10.2307/1911028

[4] Smeeding, T. (1993) Poverty, Inequality and Family Living Standards across Seven Nations. Review of Income and Wealth, 39, 229-256. http://dx.doi.org/10.1111/j.1475-4991.1993.tb00458.x

[5] Sen, A. (1976) Poverty: An Ordinal Approach to Measurement. Econometrica: Journal of the Econometric Society, 44, 219-231. http://dx.doi.org/10.2307/1912718

[6] Sahn, D.E. and Stifel, D. (2003) Exploring Alternative Measures of Welfare in the Absence of Expenditure Data. Review of Income and Wealth, 49, 463-489. http://dx.doi.org/10.1111/j.0034-6586.2003.00100.x

[7] Rati, R. (1982) Composite Indices of Physical Quality of Life. Journal of Development Economics, 11, 227-248. http://dx.doi.org/10.1016/0304-3878(82)90005-0

[8] Thon, D. (1979) On Measuring Poverty. Review of Income and Wealth, 25, 429-439. http://dx.doi.org/10.1111/j.1475-4991.1979.tb00117.x

[9] Caminada, K., Kees, G. and Ferry, K. (2011) Social Income Transfers and Poverty: A Cross-Country Analysis for OECD Countries. International Journal of Social Welfare, 21, 115-126. http://dx.doi.org/10.1111/j.1468-2397.2011.00815.x

[10] Jannati, J. and Gornick, C. (2010) Child Poverty in Upper-Income Countries: Lessons from Luxemburg Poverty Study. Luxemburg Center for Population, Luxemburg.

[11] Szarfenberg, R. (2012) Ubostwoi Wyklucznie Spoleczne (Poverty and Social Exclusion). Friedrich Ebert Foundation, Warsaw.

[12] United Nations Development Program (2010) Human Development Report. Oxford University Press, New York, US GDP Trading Economies (2014). http://www.tradingeconomics.com/united-states/gdp-per-capita

[13] Ubostwo w Polsce (2010). http://stat.gov.pl/cps/rde/xbcr/gus/wz_ubostwo_w_polsce_2010.pdf

[14] Data World Bank (2012).

http://data.worldbank.org/indicator/SI.POV.GINI?order=wbapi_data_value_2012+wbapi_data_value+wbapi_data_val ue-last\&sort=ascs

[15] Wskazniki Zagrozenia (2012) Word Bank. http://mojepanstwo.pl/dane/bdl wskazniki/251Data

[16] UNICEF Official Data (2013). http://www.unicef-irc.org/publications/pdf/rc10_eng.pdf

[17] Branko, M. (2009) Global Inequality Recalculated: The Effect of New 2005 PPP Estimates. Policy Research Working Paper 5061, World Bank, Washington DC. 
[18] Poverty and Opportunity (2013).

http://kff.org/medicare/issue-brief/poverty-among-seniors-an-updated-analysis-of-national-and-state-level-poverty-rate s-under-the-official-and-supplemental-poverty-measures/

[19] Equity in Higher Education (2010).

http://siteresources.worldbank.org/EDUCATION/Resources/278200-1099079877269/547664-1099079956815/547670 -1128086743752/jamil-pub-poland-oct2010-draft.pdf

[20] Tamarind Financial Planning (2013). http://www.asa.org/policy/resources/stats

[21] Income and Poverty in the United State (2013) Current Population Reports. US Department of Commerce.

[22] Wprost (2013). http://www.wprost.pl/ar/413173/Polska-rencistow-jest-coraz-mniej-bo-o-rente-jest-coraz-trudniej

[23] Ubostwo Wsrod Dzieci w Polsce (Poverty among Children in Poland) (2008) Departament Analiz Ekonomicznych i Prognoz, Warszawa.

[24] Poverty: 2010 and 2011 (2010). http://www.census.gov/prod/2012pubs/acsbr11-01.pdf

[25] Detroit, Michigan (MI) Poverty Rate Data (2012). http://www.city-data.com/poverty/poverty-Detroit-Michigan.html 